\title{
SEISMIC VULNERABILITY OF TRADITIONAL MASONRY BUILDING A CASE STUDY OF BYASI, BHAKTAPUR
}

\author{
Shyam Sundar Basukala ${ }^{1}$, Prem Nath Maskey ${ }^{2}$ \\ ${ }^{1}$ Department of Civil Engineering, Khwopa Engineering College, Libali-8, Bhaktapur, Nepal \\ ${ }^{2}$ Department of Civil Engineering, Institute of Engineering, Pulchowk, Nepal
}

\begin{abstract}
Historic buildings of Nepal are mainly constructed from masonry structure. Since masonry structures are weak in tension which leads to the failure of structure. So, to avoid possible damage in environment lives and property it is urgent to conduct vulnerability assessments. Seismic vulnerability of historic masonry buildings constructed in Bhaktapur at Byasi area is carried out for the case study. Five load bearing masonry buildings were selected out of 147 buildings considering opening percentage, storey and type of floor for modeling in SAP 2000 V10 Various methods of rapid visual screening (FEMA 154, EMS 98) are used to determine the vulnerability of the selected building. The Selected Building response is carried out by linear time history analysis. The seismic vulnerability of masonry structures is determined in terms of fragility curves which represent the probability of failure or damage due to various levels of strong ground motions for different damage state slight, moderate, extensive and collapse. From the result of Rapid Visual Screening (RVS) and Fragility curves of the buildings it is found that whole, buildings are found vulnerable from future earthquake.
\end{abstract}

Keywords: Vulnerability, masonry building, RVS, time history analysis, Fragility curves

\section{Introduction}

The vulnerability assessment constitutes an important tool in the support to decision making related with the rehabilitation, strengthening or at the worst demolition of buildings, location of lifeservices, etc. Vulnerability can be briefly defined as 'being prone to or susceptible to damage or injury' (Blaikie et al, 1994).

Traditional building stock in Bhaktapur city is of Masonry structures, which have been constructed since the earliest days of civilization. Most of these traditional structures were constructed from the combination of masonry walls, wooden floor and tiles roof system. Particularly, the main component of such structures is load-bearing masonry walls. Generally, the load bearing masonry is made of bricks with mud or lime mortar. Therefore, such structures are most

\footnotetext{
*Corresponding author: Shyam Sundar Basukala

Department of Civill Engineering, Khwopa Engineering,

College, Libali-8, Bhaktapur, Nepal

Email: basukala.chanchal@gmail.com
}

(Received: 2016 Sept 09 Accepted: 2016 Nov 09) vulnerable during an earthquake. Unreinforced Masonry structures showed poor performance evidence on the past earthquakes.

Nepal has many old cities, which are important from its traditional view point. But from structural view point they are more vulnerable to earthquake. So the damage evaluation is most necessary for such cities so that pre damage controlling can be done for the disaster mitigation. This will help in reduction of human loss as well as prevention of the cultural city.

\section{Building Survey}

Survey area is located in the historic city of Bhaktapur, which is located in the north east from the historic place Bhaktapur Durbar Square. We have collect data of 147 numbers of buildings. The survey location map and study area is shown in Fig 1, the main purpose of the structural survey of the buildings is to record the structural condition of the buildings. During the survey according to building storey, 5 storey building are higher in number, which is shown in Table $1 \& 2$. 


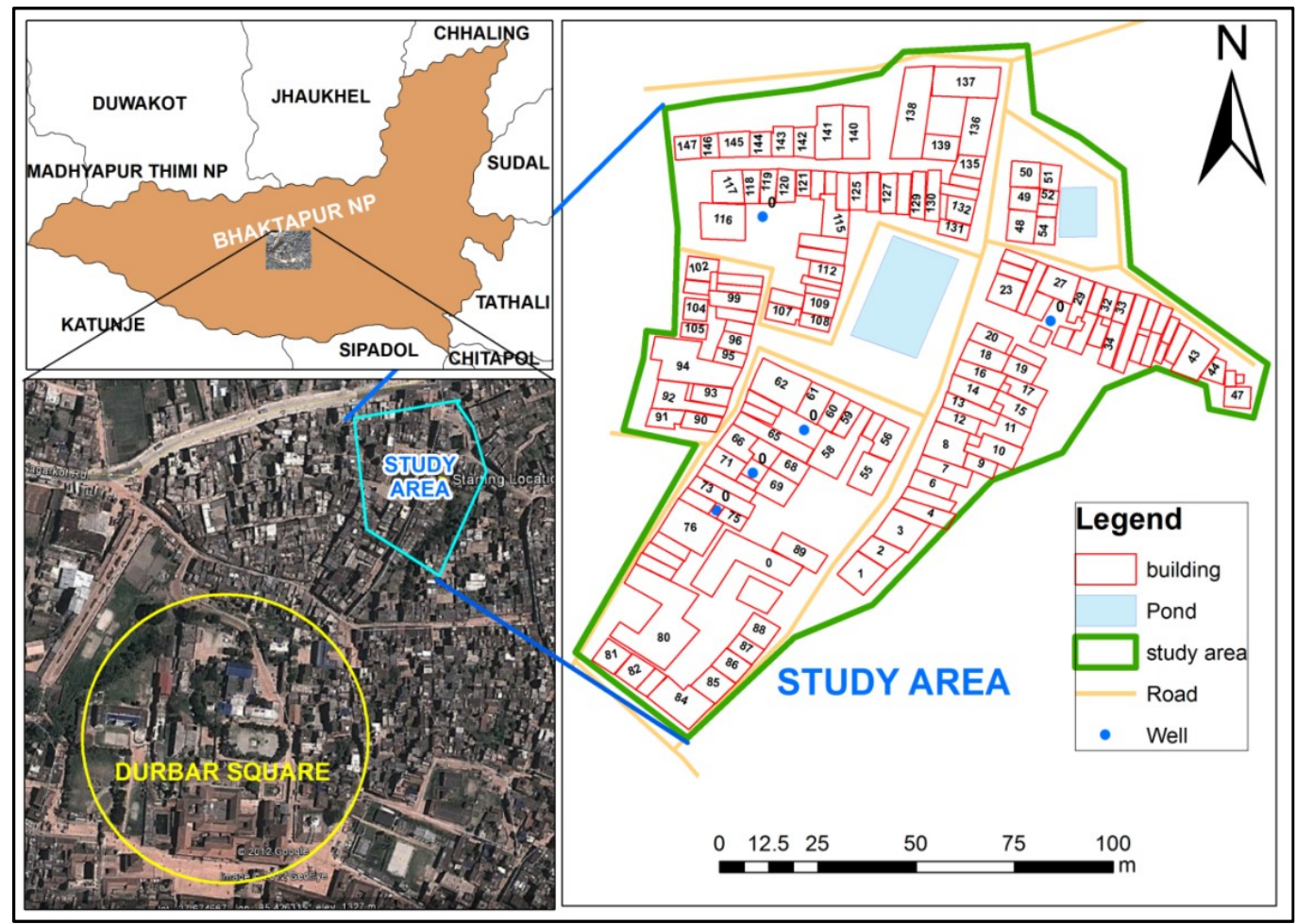

Fig 1 Survey Location Map

Table 1 Summary of Building Survey

\begin{tabular}{|c|c|c|c|c|c|c|c|c|c|}
\hline \multicolumn{2}{|c|}{ Storey No } & 2 & 3 & 4 & 5 & 6 & $\begin{array}{l}\text { Sub } \\
\text { Total }\end{array}$ & $\begin{array}{l}\text { Grand } \\
\text { Total }\end{array}$ & Remark \\
\hline \multicolumn{2}{|c|}{ Building Nos } & 2 & 7 & 59 & 77 & 2 & 147 & 147 & \\
\hline \multirow{2}{*}{$\begin{array}{l}\text { Load Bearing } \\
\text { wall }\end{array}$} & RCC Floor & 0 & 0 & 2 & 2 & 0 & 4 & \multirow{4}{*}{147} & \\
\hline & Timber Floor & 1 & 6 & 52 & 71 & 2 & 132 & & \\
\hline \multirow{2}{*}{ RCC Frame } & Timber Floor & 0 & 0 & 1 & 2 & 0 & 3 & & \\
\hline & RCC Floor & 1 & 1 & 4 & 2 & 0 & 8 & & \\
\hline \multirow{5}{*}{ Age } & $0-29$ & 1 & 3 & 12 & 11 & 0 & 27 & \multirow{5}{*}{147} & \\
\hline & $30-49$ & 1 & 3 & 10 & 21 & 1 & 36 & & \\
\hline & $50-69$ & 0 & 1 & 3 & 6 & 0 & 10 & & \\
\hline & $70-99$ & 0 & 0 & 7 & 15 & 0 & 22 & & \\
\hline & $>100$ & 0 & 0 & 27 & 24 & 1 & 52 & & \\
\hline \multicolumn{2}{|c|}{ Height Difference between floors } & 0 & 2 & 25 & 32 & 2 & 61 & 61 & \\
\hline \multirow[b]{2}{*}{$\begin{array}{l}\text { Opening \% } \\
\text { ( From Façade ) }\end{array}$} & $<30$ & 2 & 5 & 44 & 51 & 0 & 102 & & Opening \\
\hline & $>30$ & 0 & 2 & 14 & 22 & 2 & 45 & 147 & $\begin{array}{l}\text { Framed } \\
\text { buildging } \\
\text { is } \\
\text { considered } \\
\text { as } 0 \%\end{array}$ \\
\hline \multicolumn{2}{|c|}{ Large opening at GF } & 0 & 1 & 6 & 6 & 1 & 14 & 14 & \\
\hline \multirow{2}{*}{\multicolumn{2}{|c|}{$\begin{array}{l}\text { Modification/repair of Building } \\
\text { Damage building }\end{array}$}} & 0 & 0 & 34 & 48 & 2 & 84 & 84 & \\
\hline & & 1 & 3 & 44 & 61 & 2 & 111 & 111 & \\
\hline
\end{tabular}


Table 2 Building Categories

\begin{tabular}{|c|c|c|c|c|c|c|}
\hline \multirow[t]{2}{*}{$\mathrm{SN}$} & \multirow{2}{*}{$\begin{array}{l}\text { Building } \\
\text { Category }\end{array}$} & \multirow{2}{*}{$\begin{array}{c}\text { Selected } \\
\text { Building No. }\end{array}$} & \multicolumn{2}{|c|}{ Selection Criteria } & \multirow{2}{*}{$\begin{array}{c}\text { Total No. } \\
\text { Represented }\end{array}$} & \multirow[t]{2}{*}{ Remark } \\
\hline & & & Opening $\%$ & Storey & & \\
\hline 1 & $\mathrm{~A}$ & 8 & $<30$ & 5 & 48 & \multirow{4}{*}{$\begin{array}{c}\text { Timber floor } \\
\text { load bearing } \\
\text { structure }\end{array}$} \\
\hline 2 & $\mathrm{~B}$ & 93 & $>30$ & 5 & 23 & \\
\hline 3 & $\mathrm{C}$ & 109 & $<30$ & 4 & 39 & \\
\hline 4 & $\mathrm{D}$ & 118 & $>30$ & 4 & 13 & \\
\hline 5 & $\mathrm{E}$ & 143 & $>30$ & 4 & 4 & RCC floor \\
\hline
\end{tabular}

\subsection{Selection of Buildings for Modeling}

During selection of buildings for modeling and analysis various factors such as number of storey, opening percentage (consider façade only) and structure type was considered. Five buildings were selected from A to E(Table 2) based on given selection criteria. For instance, type $\mathrm{A}$ is represented by criteria of opening percentage less than 30 and five storey, which is represented by building number 8 of surveyed buildings 48 such building was found.

\section{Vulnerability Analysis of Survey Buildings}

RVS, FEMA 154, EMS 98 was used for the vulnerability analysis of the selected building. The result of Vulnerability analysis is shown in Table 3 .

Table 3 RVS result of buildings

\begin{tabular}{|c|c|c|c|}
\hline \multirow{2}{*}{ SN } & $\begin{array}{c}\text { Building } \\
\text { No. }\end{array}$ & $\begin{array}{c}\text { FEMA 154 } \\
\text { Score (S) }\end{array}$ & EMS-98 \\
\cline { 4 - 4 } & & & Damage Grade \\
\hline 1 & 8 & 0.3 & Grade 2 \\
\hline 2 & 93 & 0.8 & Grade 1 \\
\hline 3 & 109 & 0.3 & Grade 3 \\
\hline 4 & 118 & 0.3 & Grade 1 \\
\hline 5 & 143 & 0.8 & No damage \\
\hline
\end{tabular}

\section{Building Modeling}

For masonry buildings, the stiffness depends on wall thickness, geometry and openings. So for the real buildings of Byasi area having different storey was taken for the analysis is modeled to determine the distribution of seismic forces between masonry and timber framed walls. Three dimensional thin shell modeling has been carried out for research purpose. Masonry wall is modeled as bi-dimensional thin shell element of thickness 0.6 to $0.14 \mathrm{~m}$ according to sample building plan. Hinged assigned at wall support is an ideal case. For timber floor, two way equivalent timber floors hinged at the wall support is done. In this thesis, timber in both directions was provided assuming only one direction timber acts one at a time i.e. for a direction of seismic force, only lateral direction timber provides stiffness. Equivalent timer is obtained as timber floor of depth $15 \mathrm{~cm}$ and width $10 \mathrm{~cm}$ at spacing of $20 \mathrm{~cm} \mathrm{c} / \mathrm{c}$ spacing and planks of $2.5 \mathrm{~cm}$ at span of $100 \mathrm{~cm}$.

\section{The materials properties for the modal analysis:}

For Masonry wall (Thapa, 2011)

Weight per unit volume $(\Upsilon)=17.68 \mathrm{KN} / \mathrm{m}^{3}$

Poisson ratio $(\mathrm{v})=0.25$

Avg. shear strength $=0.142 \mathrm{~N} / \mathrm{mm}^{2}$

Modulus of elasticity $(\mathrm{E})=632.21 \mathrm{~N} / \mathrm{mm}^{2}$

Coefficient of friction $(\mu)=0.25$

Compressive strength $=0.56 \mathrm{~N} / \mathrm{mm}^{2}$

For timber (IS $883: 1994,1994$ )

Weight per unit volume $(\Upsilon)=8.05 \mathrm{KN} / \mathrm{m}^{3}$

Modulus of elasticity $(E)=12600 \mathrm{~N} / \mathrm{mm}^{2}$

Concrete (IS 883 : 1994, 1994)

Modulus of elasticity $(E)=5000 \sqrt{ } f_{c k}$,

Strength of concrete $\left(\mathrm{f}_{\mathrm{ck}}\right)=15 \mathrm{~N} / \mathrm{mm}^{2}$

Poisson's ratio $=0.2$

Unit weight of concrete $=24 \mathrm{KN} / \mathrm{m}^{3}$

Gravity load was calculated on the basis of unit weight of material and live load was taken as 2 $\mathrm{KN} / \mathrm{m}^{2}$. Models were designed using SAP $2000 \mathrm{~V}$ 10. The models for the analysis are shown in Fig 2. 


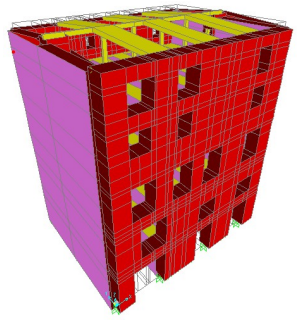

Building No.8

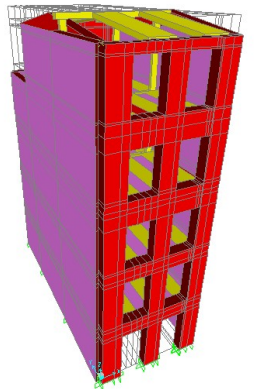

Building No. 93

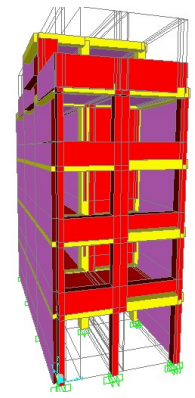

Building No.143

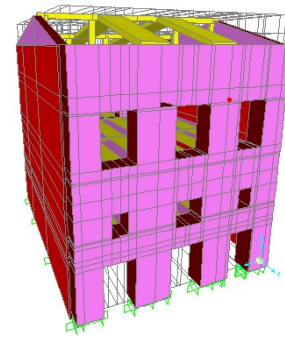

Building No. 109

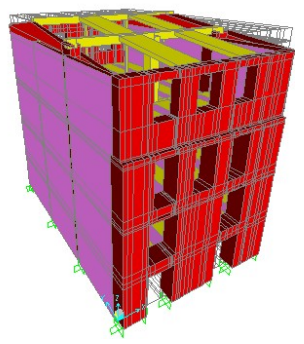

Building No. 118

Fig 2 Models of samples buildings

\section{Method of Analysis}

After the completion of modeling in SAP 2000 V10, modal analysis was carried out. Linear time history analysis was carried out for different earthquake with scaling PGA. Chamauli earthquake with $\mathrm{PGA}=0.45866 \mathrm{~g}$ and Lalitpura with $\mathrm{PGA}=0.4367 \mathrm{~g}$. The PGA is rescaled to $0.2 \mathrm{~g}, 0.3 \mathrm{~g}, 0.45 \mathrm{~g}, 0.6 \mathrm{~g}, 0.75 \mathrm{~g}, 0.9 \mathrm{~g}$ and $1 \mathrm{~g}$. From linear time history analysis, top displacements of building are determine for different rescaled PGA.

\subsection{Seismic Input}

Ground motions assumed for use in this research are synthetic earthquake that consists of a simulated ground motions time history of Chamauli and Lalitpura are shown in Fig 3. These ground motion time history contains simulated data for $10 \%$ in 50 years probability of exceedence.

\subsection{Damage States}

In this research damage states from HAZUS(Hazards U.S.) is adopted according to its assumption that the total variability of each equivalent-PGA structural damage state ( $\beta \mathrm{SPGA}$ ) is modeled by the combination of following two contributors to damage variability, uncertainty in the damage-state $\beta \mathrm{M}(\mathrm{SPGA})=0.4$ and variability in response $\beta \mathrm{D}(\mathrm{V})=0.5$.The two contributors to damage state variability are assumed to be $\log$ normally distributed, independent random variables and the total variability is simply the square- root-sum-of-the-squares combination of individual variability terms $\beta$ SPGA $=0.64$ for all damage states (Slight, Moderate, Extensive and Complete damage).

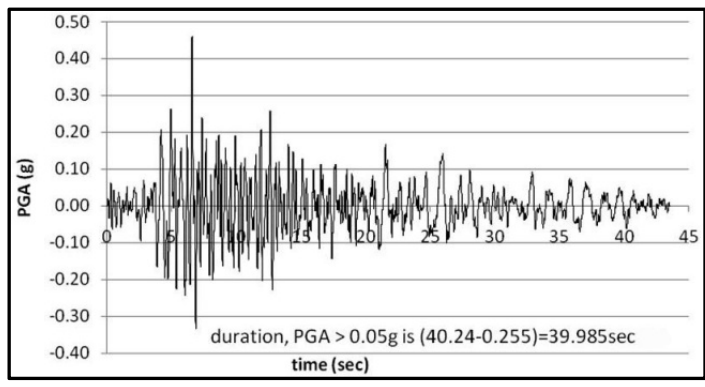

Fig 3 (a) Time history graph of Chamauli

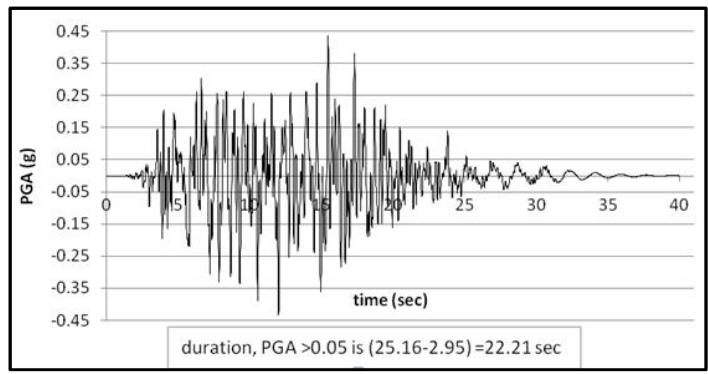

Fig 3 (b) Time history graph of Lalitpura

Four damage states are used as the capacity of the building (GIovinazzi et al. 2006)

Slight $=0.7 \mathrm{~d}_{\mathrm{y}}$,

Moderate $=1.5 \mathrm{~d}$,

Extensive $=0.5\left(\mathrm{~d}_{\mathrm{y}}+\mathrm{d}_{\mathrm{u}}\right)$,

Complete $=\mathrm{d}_{\mathrm{u}}$

where,

$\mathrm{d}_{\mathrm{y}}=$ yield displacement $=0.27 \mathrm{inch}$

$\mathrm{d}_{\mathrm{u}}=$ Ultimate displacement $=1.81$ inch 


\section{Result and Discussion}

Then linear time history analysis was performed for response of the selected buildings. The results were in terms of maximum (top) displacements. The fragility curves of each building with four damage states namely slight, moderate, extensive and complete for two earthquakes: Chamauli and lalitpura are demonstrated. These are derived from response and capacity analysis of the buildings.

The responses of other buildings in term of top displacements shows that the Lalitpura earthquake produce more displacement compared to Chaumali earthquake; however, the result is opposite for the case of building no 143 (Table 4).

\section{Fragility analysis:}

Fig 4 and 5 shows the fragility curves, which show probability of failure for different intensities of earthquake (PGA) as seismic input of chamauli and lalitpura earthquake with different damage state slight, moderate, extensive and collapse.

From the seismic hazard analysis map of Nepal, it is shown that peak ground acceleration for $10 \%$ exceedence probability in 50 years (return period is 475 years) is expected to be $0.4 \mathrm{~g}$ near Kathmandu valley. The probability of failure of the buildings is observed for the value of peak ground acceleration at $0.4 \mathrm{~g}$. This is why the peak ground acceleration value $0.4 \mathrm{~g}$ is considered in the current analysis.

\section{Chamauli earthquake as seismic input:}

The damage states for the fragility analysis were defined based on the values of probability of failure obtained from the fragility curve. Using the chamauli earthquake as seismic input to the time history analysis, the probability of failure is slight damage state to moderate state for building number 8 and 118 at $0.4 \mathrm{~g}$ PGA. From the analysis it can be seen that building number 93 and 143 will be damaged extensive to complete damage state (Table5).

\section{Lalitpura earthquake as seismic input:}

In case of the lalitpura earthquake as a seismic input the probability of failure for building number 8 and 118 at $0.4 \mathrm{~g}$ PGA is moderate damage state. From the fragility analysis building number 93 will be damaged extensive to complete damage state whereas, for building number 143 extensively damage sate. It can be seen that in comparison to other buildings, building number 109 will be less vulnerable i.e. it will have slight damage according to fragility analysis (Table6).

From fragility analysis probability of failure of building number 93 and 143 is very high because the damage state exceeds $50 \%$ in extensive damage state (Table $5 \& 6$ ).

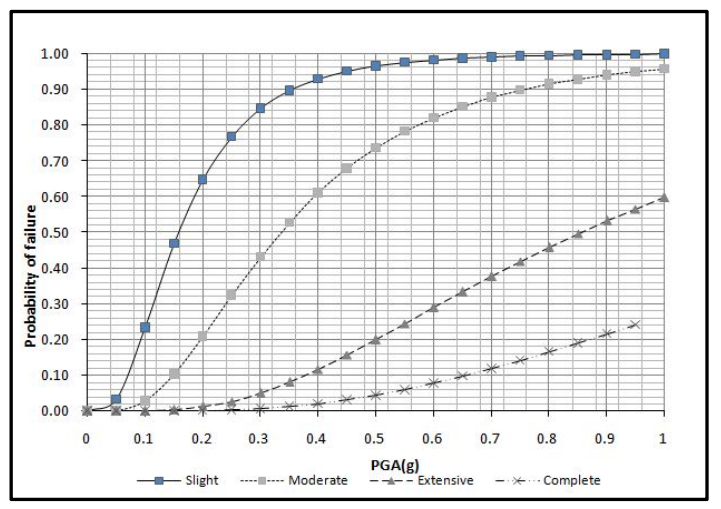

Fig 4 Fragility Curve of building no. 8 for various damage state at chamauli earthquake

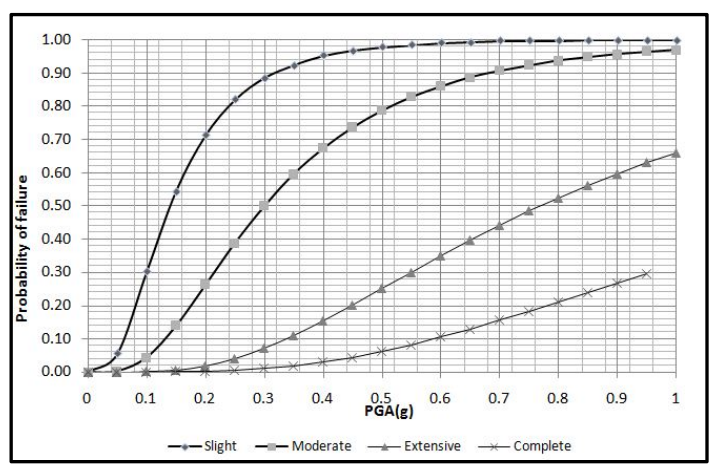

Fig 5 Fragility Curve of building no. 8 for various damage state at lalitpura earthquake

From fragility analysis probability of failure of building number 93 and 143 is very high because the damage state exceeds $50 \%$ in extensive damage state (Table $5 \& 6$ ). 
Comparison between RVS method and Fragility curve:

From the analyses, it is shown that FEMA 154, Method the buildings are vulnerable in context of high seismic zone. Similarly, from the EMS-98 analysis, the damages could be seen in all the buildings except building number 143. In this regard all of these methods suggest that a detail analysis is sought for the building. The detail analysis carried out using fragility analysis building number 93 is vulnerable to very heavy damage, building number 143 is vulnerable to heavy damage whereas building numbers 8 and 118 are vulnerable to moderate damage and building number 109 is vulnerable to slight damage. According to EMS-98 method these building showed different scenario in comparison to analytical method (Table 7).

Table 4 Top (max.) displacement Building (Demand)

\begin{tabular}{|c|c|c|c|c|c|c|c|c|c|c|}
\hline \multirow{3}{*}{$\begin{array}{c}\text { PGA } \\
(\mathrm{g})\end{array}$} & \multicolumn{10}{|c|}{ Buildings Response as Top (max.) displacement (mm) } \\
\hline & \multicolumn{2}{|c|}{ Bldg no 8} & \multicolumn{2}{|c|}{ Bldg no 93} & \multicolumn{2}{|c|}{ Bldg no 109} & \multicolumn{2}{|c|}{ Bldg no 118} & \multicolumn{2}{|c|}{ Bldg no 143} \\
\hline & 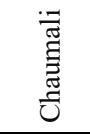 & 莺 & 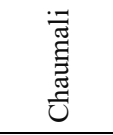 & 茑 & 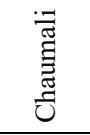 & 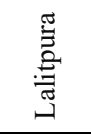 & 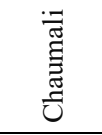 & 莺 & 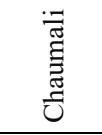 & 莺 \\
\hline 0.2 & 6.19 & 6.868 & 24.017 & 30.448 & 1.712 & 1.790 & 5.404 & 5.675 & 18.588 & 11.284 \\
\hline 0.3 & 9.287 & 10.301 & 36.026 & 45.669 & 2.568 & 2.696 & 8.105 & 8.511 & 27.882 & 16.117 \\
\hline 0.45 & 13.409 & 15.453 & 54.03 & 68.507 & 3.852 & 4.045 & 12.157 & 12.768 & 41.821 & 25.389 \\
\hline 0.6 & 18.575 & 20.603 & 72.046 & 91.338 & 5.136 & 5.393 & 16.209 & 17.022 & 55.760 & 33.851 \\
\hline 0.75 & 23.218 & 25.754 & 90.057 & 114.176 & 6.420 & 6.742 & 20.261 & 21.280 & 69.699 & 42.315 \\
\hline 0.9 & 27.719 & 30.906 & 108.073 & 137.014 & 7.704 & 8.091 & 24.315 & 25.537 & 83.643 & 50.779 \\
\hline 1 & 29.167 & 34.339 & 120.076 & 152.235 & 8.560 & 8.990 & 27.015 & 28.374 & 92.932 & 56.420 \\
\hline
\end{tabular}

Table 5 Probability of failure of building for PGA $=0.4 \mathrm{~g}$ for chamauli earthquake

\begin{tabular}{|c|c|c|c|c|c|c|}
\hline \multirow[b]{2}{*}{ SN. } & \multirow[b]{2}{*}{ Building No. } & \multicolumn{4}{|c|}{ Probability of failure (\%) } & \multirow[b]{2}{*}{ Damage State } \\
\hline & & Slight & Moderate & Extensive & Complete & \\
\hline 1 & 8 & 93 & 62 & 12 & 0.2 & moderate \\
\hline 2 & 93 & 100 & 100 & 82 & 53 & heavy \\
\hline 3 & 109 & 30 & 4 & 0 & 0 & slight \\
\hline 4 & 118 & 90 & 55 & 8 & 1 & moderate \\
\hline 5 & 143 & 100 & 98 & 71 & 38 & heavy \\
\hline
\end{tabular}

Table 6 Probability of failure of building for PGA $=0.4 \mathrm{~g}$ for lalitpura earthquake

\begin{tabular}{|c|c|c|c|c|c|c|}
\hline \multirow{2}{*}{ SN. } & \multirow{2}{*}{$\begin{array}{c}\text { Building } \\
\text { No. }\end{array}$} & \multicolumn{4}{|c|}{ Probability of failure $(\%)$} & \multirow{2}{*}{ Damage State } \\
\cline { 3 - 6 } & & Slight & Moderate & Extensive & Complete & moderate \\
\hline 1 & 8 & 95 & 68 & 15 & 0.25 & very heavy \\
\hline 2 & 93 & 100 & 100 & 90 & 67 & slight \\
\hline 3 & 109 & 33 & 5 & 0 & 0 & moderate \\
\hline 4 & 118 & 92 & 57 & 10 & 2 & heavy \\
\hline 5 & 143 & 99 & 89 & 40 & 13 & \\
\hline
\end{tabular}

Table 7 Comparison between RVS method and Fragility curve of building

\begin{tabular}{|c|c|c|c|c|}
\hline \multirow{3}{*}{ SN. } & \multirow{3}{*}{$\begin{array}{c}\text { Building } \\
\text { No. }\end{array}$} & \multicolumn{2}{|c|}{ Rapid Visual Screening } & \multirow{2}{*}{ Analytical Method (Fragility curve) } \\
\hline & & FEMA 154 & EMS-98 & \\
\hline & & Score $(\mathrm{S})$ & Damage Grade & Damage State \\
\hline 1 & 8 & 0.3 & Grade 2 & moderate \\
\hline 2 & 93 & 0.8 & Grade 1 & Very heavy \\
\hline 3 & 109 & 0.3 & Grade 3 & slight \\
\hline 4 & 118 & 0.3 & Grade 1 & moderate \\
\hline 5 & 143 & 0.8 & No damage & heavy \\
\hline
\end{tabular}




\section{Conclusion}

Five buildings of different storey and floor type are taken for the analysis from RVS and analytical method. The fragility curves shows buildings are in vulnerable state. The curves are useful for pre-disaster planning and loss i.e. lives and property estimation of masonry building due to potential earthquake.

The following major conclusions are drawn from the current research.

1. For the selected buildings with opening percentage greater than $30 \%$ shows high degree of damage compare to the other building with less opening.

2. Wall continuity in elevation also shows grate effect in the performance of building.

3. Evaluation of structure with two different earthquakes shows similar result for given structure.

4. Fragility curves are different for different buildings due to the variation in modal frequencies, plan irregularities, height irregularities and openings.

5. The maximum Top displacement for Building no 8 for $1 \mathrm{~g}$ is $30.95 \mathrm{~mm}$ for Chamauli and Lalitpura is $34.33 \mathrm{~mm}$. This variation in displacement is due variation in duration and frequency content. Similar variation in displacement can be seen in other building as well.

The fragility curves when read along with seismic hazard map will provide excellent decision making information about retrofit requirement of masonry structures. So, it is recommended to update the seismic hazard map all over the country.

\section{References}

[1] Arya, A. S. (2008). Seismic Assessment of Masonry Buildings. Journal of South Asia Disaster Studies, 1 (1).
[2] Blaikie, P. C. (1994). At risk. Natural hazards, people's vulnerability and disasters.

[3] Colangelo, F. (2008, October 12-17). On The Computation Of Seismic Fragility Curves. 14th World Conference On earthquake engineering .

[4] D’Ayala1, D. D. (2004). Correlation Of Fragility Curves For Vernacular Building Types: Houses In Lalitpur, Nepal And In Istanbul, Turkey. 13th World Conference on Earthquake Engineering (485).

[5] E.Speranza, D. D. (2003). An Integrated Procedure For The Assessment Of Seismic Vulnerability Of Historic Buildings. Of Seismic Vulnerability Of Historic Buildings. 12th European Conference on Earthquake Engineering .

[6] FEMA 154, Rapid Visual Screening of Buildings for Potential Seismic Hazards: A HANDBOOK (2nd Edition ed.). (March 2012).

[7] Grünthal, G. (Ed.). (1998). European Macroseismic Scale 1998 EMS-98. 15.

[8] IS 883 : 1994. (1994). Design Of Structural Timber In Building - Code Of Practice . Bureau of Indian Standards.

[9] K. Nasserasadi, M. G.-A. (2009). Developing Seismic Fragility Functions Of Structures By Stochastic Approach.

[10] M. Rota1, A. P. (2008, October 12-17). A Procedure For Deriving Analytical Fragility Curves For Masonry Buildings. The 14 .

[11] Maskey, P. N. (2002). Seismic Risk of Bhaktapur City and It's Monumental structures. PhD Thesis, Tribhuvan University, Department of Civill Engineering.

[12] Ranganathan, R. (1990). Reliability Analysis and Design of Structures. NewDelhi, India.: TATA McGRAW7Hill Publishing Company Limited.

[13] Thapa, J. B. (2011). Test and Simulation of Brick Masonry Wall of Historical Buildings. M.Sc. Thesis, I.O.E. Pulchowk Campus, Department of Civil Engineering.

[14] Glovinazzi et al (2006).Displacement capacity of ancient structures through non -linear kinematic and dynamic analyses 